\title{
Shatavari (Asparagus Racemosus) - The Best Female Reproductive Tonic
}

\author{
Shifali Thakur ${ }^{1}$, Hemlata Kaurav ${ }^{2}$, Gitika Chaudhary ${ }^{3}$ \\ ${ }^{1}$ Junior Research Executive, ${ }^{2}$ Research Associate, ${ }^{3}$ HOD Research and Development, \\ Shuddhi Ayurveda, Jeena Sikho Lifecare Pvt. Ltd. Zirakpur 140603, Punjab, India. \\ Corresponding Author: Gitika Chaudhary
}

\begin{abstract}
It is recommended by the World health organization (WHO) the most of the world's population depends on herbal medicine for their health care. Shatavari, Asparagus racemosus is one of the most significant restorative plant employed by Ayurvedic Vaidyas from ancient times. This herbal plant has wide selection of biological activities and described as a Rasayan in Ayurvedic literatures. Root is the most used part of Shatavari by Ayurvedic Vaidyas. It is one of the most common herbal plant used worldwide and possess various chemical constituents such as Racemoside A, B, C, Shatavarins, Asparanin A, Immunoside, $27 \alpha$ dimethyl-1 $\beta, 2 \beta, 3 \beta$-trihydroxy-25-spirost-4-en$19 \beta$-oic, $27 \alpha$-dimethyl-1 $\beta, 2 \beta, 3 \beta$-trihydroxy25 -spirost-4-en-19 $\beta$-oic and many others. It is described as a tonic and have lactogenic properties. It has an extensive use in Nervine disorders, Acid peptic diseases, several contagious ailments and as a immunomodulant. It is primarily used in female ailments mainly as galactagogic and several menstrual problems. The chemical constituents of Asparagus racemosus have many pharmacological activities such as antibacterial, antiviral, antiinflammatory, wound healing effect, antidepressant, anti-anxiety, antifertility and also skin cancer, pigmentation and many other. Much scientific research on Asparagus racemosus has been conducted over the last years to investigate chemical and pharmacological properties. In this review, the general description, phytochemicals, pharmacological properties, ayurvedic properties and folk uses of Asparagus racemosus are briefly explained.
\end{abstract}

Keywords: Shatavari, Ayurveda, Saponins, Menstrual disorders, Anti-ulcer, Immunomodulatory.

\section{INTRODUCTION}

Medicinal herbs are the nature's blessing to mankind to have sound life, a disease free life. India is one of the foremost medico-culture nation in the globe where the medicinal herb divide in a component of a classical custom that's honoured even in the modern era. Due to the worldwide trend for the enhanced 'quality of life', there is need to rise the utilization of restorative herbs ${ }^{[1]}$. India is abundantly enriched with a good sort of herbs having therapeutic worth ${ }^{[2]}$. Shatavari is most commonly used Ayurvedic herb ${ }^{[3]}$. Its therapeutic properties are described broadly in Traditional medicinal system such as Ayurveda, Siddha and Unani ${ }^{[4]}$. The word Shatavari indicates "who acquires 100 husbands or sufficient to many". it's advised both as typical tonic or a female reproductive tonic. Shatavari (Figure 1) can also be depicted as "100 spouses", signifying its capacity to extend fertility and endurance. In Ayurveda this wonderful plant is called as the "Queen of Herbs" as it encourages love and passion. It is that the major Ayurvedic revitalize drug for females ${ }^{[5]}$. More than 250 species comprise in genus Asparagus throughout the world in which 22 species of Asparagus are found in India. The Asparagus genus is advised to have therapeutic importance due to the presence of various phytochemicals like steroidal 
saponins and sapogenins in different parts of the plant ${ }^{[6]}$. The plant possesses various properties like ageing, increases endurance, provides immunity enhances mental function, strength and add spunk to the body and it's also utilized in mental disorders, heartburn, cancer, irritation, neuropathy, hepatopathy. Studies have revealed that its root extracts possess properties like antiulcer, anti-oxidant, anti-diarrheal, antidiabetic, immunomodulatory ${ }^{[7]}$. This review aims at exploring every medicinal view like Folk, Ayurveda and Modern on shatavari plant. The taxonomical classification and vernacular names of Asparagus racemosus is shown in table no. 1 and table no. 2 respectively ${ }^{[8]}$.

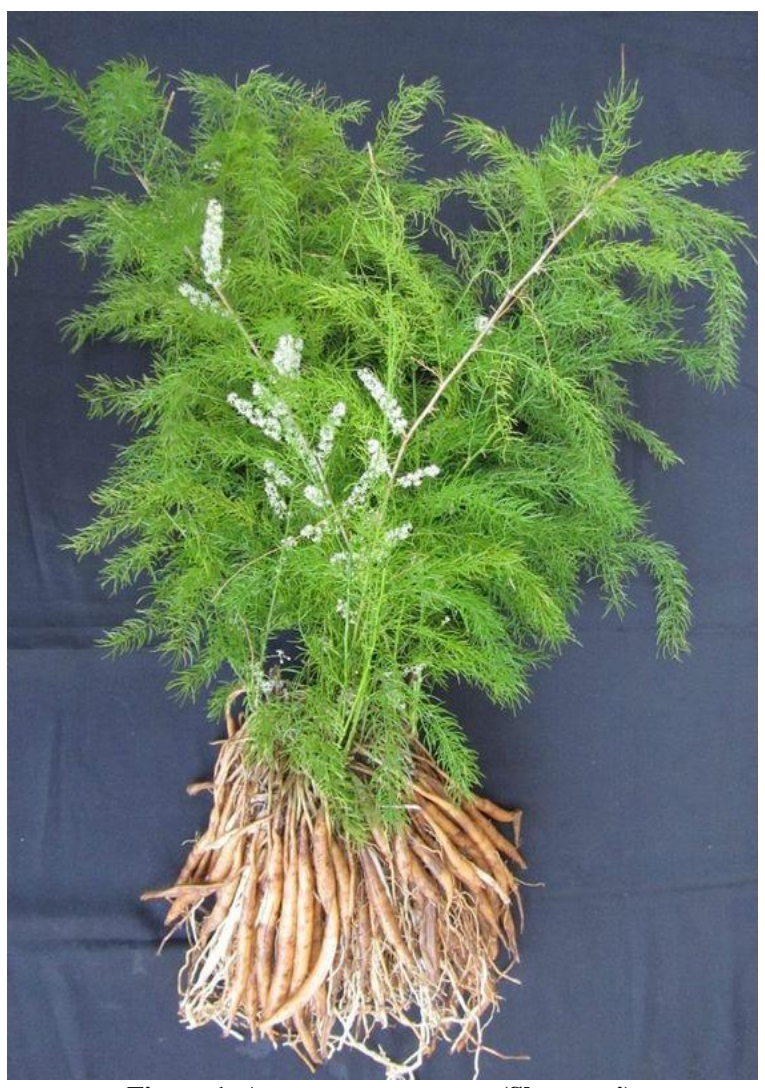

Figure 1. Asparagus racemosus (Shatavari)

Table 1: Taxonomy of Asparagus racemosus

\begin{tabular}{|l|l|}
\hline Taxonomical Rank & Taxon \\
\hline Kingdom & Plantae \\
\hline Division & Angiosperms \\
\hline Class & Monocots \\
\hline Order & Asparagales \\
\hline Family & Asparagaceae; Liliaceae \\
\hline Genus & Asparagus \\
\hline Species & Racemosus \\
\hline Common Name & Shatavari \\
\hline
\end{tabular}

Table 2: Vernacular names of Asparagus racemosus

\begin{tabular}{|l|l|}
\hline English & Wild asparagus \\
\hline Hindi & Satavari, Shatawar or Satmuli \\
\hline Sanskrit & Satavari \\
\hline Bengali & Shatamuli \\
\hline Marathi & Shatavari or Shatmuli \\
\hline Gujarati & Satawari \\
\hline Telegu & Toala-gaddalu or Pilli-gaddalu \\
\hline Tamil & Shimaishadavari or Inli-chedi \\
\hline Malayalam & Chatavali \\
\hline Kannada & Majjigegadde or Aheruballi \\
\hline Madhya Pradesh & Narbodh or atmooli \\
\hline Rajasthan & Norkanto or Satawar \\
\hline Himachal Pradesh & Sanspayiin \\
\hline
\end{tabular}

\section{Botanical Distribution of Asparagus racemosus (Shatavari)}

Plants are under-shrub and grow up to the height of 3 meters. This is a spinous herb that consists of a lot of short root succulent ${ }^{[11]}$. The roots of the plant are elongated, tuberous brownish with tapered tip on both sides. It grows up to $25-90 \mathrm{~cm}$ of height and 1-2 $\mathrm{cm}$ of thickness that appear silver white internally or externally. This plant is a woody climber known as "Liana Bearing Brown" or changes its colour whitish to grey ${ }^{[12,13]}$ and having protective pine needles on the top of the leaves. The flowers are uniform and small bloomed in February-March. Their flowers are hermaphrodite, aromatic and is mainly polluted by bees ${ }^{[14]}$. Fruits having attractive red barriers. Those barriers are small, round and matured from green to red. The transverse section of the root is circular or an elliptical, Periderm consists of 5-6 layers of compact cells, thin-walled phellems that extend tangentially. About 2-3 peripheral layers of cork cells are followed by one layer of phelloderm. Phelloderm followed by 6-7 layers of cortical cells. The vascular bundle is set in the middle forming a circular ring. Protoxyl arranged towards the center; While metaxylem is outward. There are extensive zones of secondary phloem. Secondary xylem wide zone, consisting of ships, tracheid and parenchyma xylem, follows secondary phloem's. Epidermal layer contains a lot of epidermal hair ${ }^{[15]}$.

Geographical Distribution of Asparagus racemosus 
The plant is distributed throughout the world basically in Sri Lanka, India and Himalayas. In India it is situated in tropical and subtropical parts that range up to 1500 $\mathrm{m}$ high distance ${ }^{[16]}$.

\section{Phytochemical constituents of Asparagus racemosus}

Many scientific studies indicated that the following active constituents are present in Plant Shatavari mentioned below (Figure 2):

1. Steroidal saponins also named as Shatvarins, Shatvarin I and VI, sarsasapogenin, asparanin $(\mathrm{A}, \mathrm{B}, \mathrm{C})$ and adcendin (A,B) extracted from the Asperagus racemosus. Shatvarin I is the significant glycoside with 3-glucose and rhamnose moieties fixed to sarsapogenin $[17,18,19,20]$

A glycoside of sarsapogenin is known as Shatavarin IV which having 2 molecules of asparagus rhammose moieties attached to sarsasapogenin. These phytoconstituents are present in roots, leaves and fruits of asparagus species. And from the recent researches Shatavarin V, Asparinins, Asparosides, Curillins, Curillosides have also been isoated from the particular plant. The major biochemical of species are shown in the Figure 1.
2. Oligospirostanoside categerized as Immunoside ${ }^{[21]}$.

3. Polycyclic alkaloid-Aspargamine A, an enclosure type pyrrolizidine alkaloid $[22,23]$

4. Isoflavones - 8-methoxy-5, 6, 4trihydroxy isoflavone-7-0-beta-Dglucopyranoside ${ }^{[24]}$.

5. A cyclic hydrocarbon-Racemosol for example dihydrophenantherene ${ }^{[25,26]}$.

6. Furan compound-Racemofuran ${ }^{[27]}$

7. Starches Polysacharides, adhesive ${ }^{[28]}$.

8. Flavanoids-Glycosides of quercitin, rutin and hyperoside are available in blossom and natural products ${ }^{[29]}$.

9. Sterols-Roots additionally contain sitosterol, 4,6-dihydryxy-2-O(- 2hydroxy isobutyl) benzaldehyde and undecanyl cetanoate ${ }^{[30]}$.

10. Minor elements - are found in roots-zinc (53.15), manganese (19.98), copper (5.29), cobalt (22.00 microgram per gram) alongside calcium, magnesium, potassium zinc and selenium ${ }^{[31,32]}$.

11. Kaepfrol-Kaepfrol alongside Sarsapogenin from woody parts of tuberous roots could be isotaled ${ }^{[33]}$.

12. Random Essential unsaturated fats Gamma Linoleinic acids, Vitamin A, Diosgenin, quercetin 3-glucourbnides [34]. Some major phytochemicals of Shatavari is mentioned in table no. 3 below

Table 3: Some Major Phytochemical Constituents of Asparagus racemosus

\begin{tabular}{|c|c|}
\hline Name & Compound \\
\hline \multicolumn{2}{|l|}{ Root extract \& Stem extract of tuberous } \\
\hline 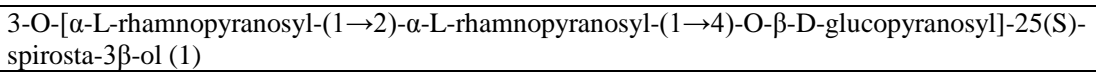 & Steroidal $^{[35]}$ \\
\hline Racemoside A, B, C & Steroidal $^{[36]}$ \\
\hline Shatavarins & Steroidal $^{[37]}$ \\
\hline Asparanin A & Steroidal ${ }^{[38]}$ \\
\hline Immunoside & Steroidal ${ }^{[38]}$ \\
\hline $27 \alpha$-dimethyl-1 $\beta, 2 \beta, 3 \beta$-trihydroxy-25-spirost-4-en-19 $\beta$-oic & Steroidal $^{[39]}$ \\
\hline Sarsasapogenin & Steroidal $^{[40]}$ \\
\hline Diosgenin & Steroidal $^{[40]}$ \\
\hline Sitosterol & Steroidal $^{[41,42,43]}$ \\
\hline Anti-HIV compounds & Steroidal $^{[44]}$ \\
\hline Filiasparoside C & Steroidal $^{[45]}$ \\
\hline Shatavaroside A & Steroidal $^{[46]}$ \\
\hline Shatavaroside B & Steroidal $^{[47]}$ \\
\hline Asparagamine A & Alkaloid $^{[48]}$ \\
\hline Polycyclic alkaloid & Alkaloid $^{[49]}$ \\
\hline Racemosol (9, 10-dihydro-1, 5-dimethoxy-8-methyl-2, 7- phenanthrene diol) & $\begin{array}{l}\text { Dihydrophenanthrene derivative } \\
{[50]}\end{array}$ \\
\hline Racemofuran & Furan derivatives ${ }^{[51]}$ \\
\hline 8-Methoxy-5,6,4-trihydroxyisoflavone-7-O- $\beta$-Dglucopyranoside & Flavonoid $^{[52]}$ \\
\hline Cyanidine-3-galatoside & Flavonoid $^{[53]}$ \\
\hline
\end{tabular}




\begin{tabular}{|c|c|}
\hline \multicolumn{2}{|l|}{ Table - 3 Continued... } \\
\hline \multicolumn{2}{|l|}{ B. Leaves } \\
\hline Kaempferol & Flavonoid $^{[53]}$ \\
\hline 5-hydroxy-3,6,4'-trimethoxy-7-O- $\beta$-D-glucopyranosyl-[1 $\rightarrow 4]$-O- $\alpha$-D-xylopyranoside & Flavonoid $^{[54]}$ \\
\hline \multicolumn{2}{|l|}{ C. Flowers and fruits } \\
\hline Quercetin-3-glucuronide & Flavonoid $^{[55]}$ \\
\hline Quercetin & Flavonoid $^{[55]}$ \\
\hline Rutin & Flavonoid $^{[55]}$ \\
\hline Hyperoside & Flavonoid $^{[55]}$ \\
\hline
\end{tabular}

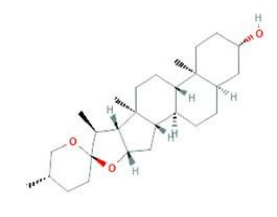

a. Sarasasapogenin

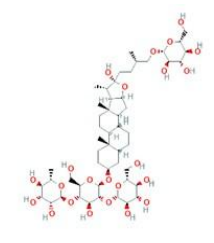

b. Shatavarin I

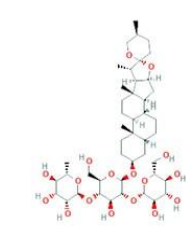

c. Shatavarin IV

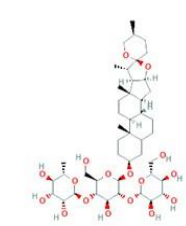

d. Shatavarin VI

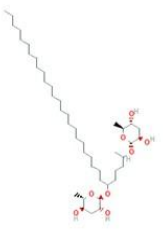

e. Asparosides C

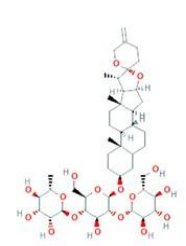

f. Shatavarin VII

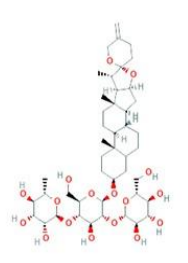

g. ShatavarinVIII

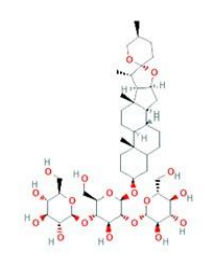

h. Shatavarin IX

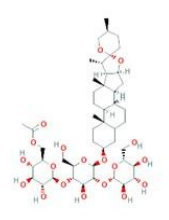

i. Shatavarin X

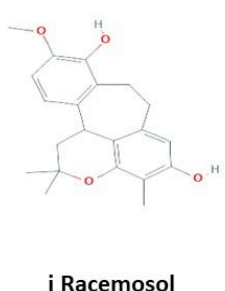

j Racemosol

Figure 2. Chemical structures of some major phytochemicals of Asparagus racemosus

\section{Traditional and Modern View}

\section{a. Folk View}

Folk medication system has most likely existed in the Indian sub-continent from the ancient times and used in Ayurveda and Unani medicinal system. Folk medication potentially existed in the Indian sub-continent at first as tribal medications, and with the ascent of the standard populace (Bengali-speaking populace in Bangladesh), tribal medicine system of the standard clan came to be known as folk medication. Folk medicinal experts are otherwise called Kavirajes or Vaidyas. Folk medication is generally used by Kavirajes to treat a particular disease with juice acquired from a plants. The Plants utilized by the Kavirajes or even ancestral healers are additionally considered as Ayurvedic drug plants by Ayurvedic specialists ${ }^{[57,58]}$. In Thailand, traditionally the decoction of roots of the Shatavari herb have been utilized as a treatment for spleen ailments, liver and other vital organs, including forestalling abortion. In India, the roots have been utilized during internal torment, tumors, fever and as a syrup ${ }^{[59]}$.

\section{b. Ayurvedic View}

Shatavari secures the honour of a rasayana in Ayurveda which means herbal medication encouraging regular health by boosting cellular endurance ${ }^{[60]}$. Shatavari is used in almost every Ayurvedic formulations like Anuthaila, Brahma rasayana, Dhanwan thararishta, Mahathikthaka kashaya, Narayana Thaila, Rasnadi kashaya, Sahacharadi thaila, Saraswatharishta, Shatavari panaka, Shatavari gritha, Shatamulyadi lehya, Vashishtha rasayana, Vitharyadi gritha ${ }^{[61,62]}$. Rasa Panchak of Shatavari [63] is mentioned in table no. 4 below:

Table 4: Rasa Panchak of Asparagus racemosus

(Shatavari)

\begin{tabular}{|l|l|}
\hline Sanskrit/English & Sanskrit/English \\
\hline Virya/Potency & Sheeta/Cold \\
\hline Vipak/Metabolic Property & Madhura/Sweet \\
\hline Guna/Physical Property & Guru,Snigadh/Heavy and Oily \\
\hline Rasa/Taste & Madhur,Tikta/Sweet and bitter \\
\hline
\end{tabular}


Shatavari is Vata and Pitta sedative. The roots are harsh, sweet, cooling, stomachic, obstructing, restoring, carminative, canapé and antispasmodic. They are valuable in apprehensive messes, dyspepsia, looseness of the bowels, diarrheal, consuming sensation, polydipsia, hyperacidity, colic and general weakness [64]. This plant is profoundly utilized in issues related with female regenerative system. Charaka Samhita composed by Charaka and Ashtang Hridyam composed by Vagbhata, the two primary texts on Ayurvedic prescriptions, list Asparagus racemosus (A. racemosus) as a method that helps in treating health related issues of females ${ }^{[65,66,67]}$. It enhances lactation in females (satanyajanana), provide strength (balya), enhances sperm count and motility (shukrala) and also helps in treating urination problems (mutrala). Extracts from the roots are used to balance the hormonal levels in female ${ }^{[68]}$. It is advantageous in female infertility, as it builds charisma, fixes aggravation of sexual organs and even humidifies dry tissues of the sexual organs [69] improves folliculogenesis and ovulation [70], prepare the belly for conceiving, forestalls miscarriages ${ }^{[71,72]}$, expands lactation, maintains the uterus and the evolving hormones ${ }^{[73]}$. Its utilization is supported in leucorrhoea and menorrhagia ${ }^{[74]}$. A. racemosus has estrogenic action.

\section{Properties of Shatavari}

- Apasmara: It is used to treat epilepsy disorder.

- Murcha: It is in loss of consciousness.

- Vatavyadhi: It is used to cure nervine disorders.

- Amlapitta: It is used against acidic reflexes or acidity.

- Shola: It is used to treat pain disorders.

- Grahani: It is used to treat duodenal problem.

- Arsha: It is used to cure haemorrhoid disease.

- Hridroga: It is used to cure cardiac disorders.
- Raktapitta: It is used to cure internal bleeding disorder.

- Shotha: It is used to reduce swelling.

- Stanyakshaya: It enhances lactation in females.

- Shukrakshaya: It is used to cure male infertility.

- Mutrakrichcha: It is used to cure urogenital disorders.

- Kshaya: It is used to cure tuberculosis.

- Daurbalya: It is used to treat weakness problem.

- Dristhimandya: It is used to treat eye sight disorders.

\section{c. Modern View}

Herbal plants and chemical constituents derived from them represent more than $50 \%$ of drugs in modern medication system. Medicinal plants synthesised into effective substances, those substances are not considered as natural product as it goes under various synthesis techniques. Since most of medicine containing Shatavari that are accessible in the market as polyhedral preparations ${ }^{[75]}$.

\section{Reported Therapeutic Studies of Asparagus racemosus}

Various studies have been conducted on this plant to know its pharmaceutical and therapeutic uses. Large-scale clinical studies are still needed to prove the clinical efficacy of this herb, especially in skin diseases, immunomodulatory disorders and cancers.

1. Reproductive Effect: It is utilized to cure the reproductive problems in females like irregularities in menstrual cycle Dysmenorrhea, Uterine Bleeding, amenorrhea, sexual weakness, Dysfunctional, menopause, pelvic inflammatory disease like sexual dysfunction and endometriosis. In ancient times it has been used for PMS as uterine tonic, thus it strengthens, nourishes, cleanses and causes uterus prolapse. It eliminates infertility and develop the uterine wall for contraction during foetus development hence prevents the miscarriage and also helps 
to increase lactation by balancing the hormonal level. It increases the weight of ovaries and improves folliculogenes and root extract is helpful in serum FSH stimulation ${ }^{[76,77,78]}$. A. racemosus consists of saponins which hinder the oxytocic action on uterine musculature, accordingly keep up the unconstrained uterine motility, affirming its utility in dysmenorrhea which includes agonizing period without huge pelvic pathology. Shatavri sidh girit is a famous shatavari formulation which is preferred in threaten abortion cases and this action is due to Shatavarin $1^{[79,80]}$.

2. Anti-carcinogen Activity: Steroidal saponins extract from the plant shatavari used for apotosis inducing study ${ }^{[81]}$. The root extract appeared to have a defensive impact in the memory cell carcinoma. Steroidal segments of the A. racemosus were researched for the apoptotic action and surmised to have the ability to tumour cell death. Shatavarin IV possess' significant anti-cancer properties ${ }^{[82,83,84]}$.

3. Anti-proliferative Activity: From the various experiment Shatavarin IV shows the most extreme potential to diminish cell viability and mortality rate ${ }^{[85,86]}$.

4. Anti-ulcer Activity: The plant shows the property of adaptogen (improve the capacity of body to changes as indicated by the climate) as referenced before, it is rasayana spice to improve the cell resistance $^{[87,88]}$. The constituents of $A$. racemosus works against ulcer. The compatible perish in measure of gastric secretion, free causticity and number of ulcer patches and acidity was analysed ${ }^{[89]}$. A. racemosus root powder is potent in persistent peptic ulcers. There was an increment in the life expectancy of gastric mucosal epithelial cells, emission and thickness of gastric bodily fluid ${ }^{[90]}$.

5. Cardio protective Activity: The supplementation of roots powder is utilized in bringing down the all-out lipid concentration, peroxidation by lowering the (cholesterol) LDL and VLDL over $40 \%{ }^{[91]}$.

6. Anti-bacterial Activity: The methanol extract originated from the roots of A. racemosus have demonstrated for antibacterial property against Vibrio cholerae, Shigella dysenteriae, Pseudomonas putida Staphylococcus aureus, Shigella flexneri, Escherichia coli, Salmonella typhi, Salmonella typhimurium, Shigella sonnei, and Bacillus subtilis ${ }^{[92,93]}$.

7. Anti- Fungal: The root extract of Shatvari provide significant protection against fungal infections such as candida, Malassezia furfur and M. globosa $^{[94,95]}$.

8. Anti-oxidant: Methanolic extract of the Shatavari imparts anti-oxidant properties. There is a significant increase in the enzymes like catalase, super-oxidase demutase and also in ascorbic acid whereas the lipid peroxidation decreases. The anti-oxidant activities are also due to the flavanols like racemofuran, asparagamine $\mathrm{A}$, racemosol. Crude and purified aqueous extract provides protection against radiation induced loss of protein thiols. Racemofuran, asparagamine A showed anti-oxidant activity against DPPH. The anti-oxidant property noticed was expected to their redox property of the phenolic mixes present in the ethanolic root extracts ${ }^{[96,97,98,99]}$.

9. Anti-depressant: The methanolic extracts are directly associated with the significant anti-depressant properties [100]

10. Hepatoprotective: The alcoholic extracts of the Shatavri roots are known to provide protectivity against increased levels of alanine transaminase, aspartate transaminase and soluble phosphatase in CC14-instigated hepatic harm in rodents. In paracetamol actuated liver injury in rodents there is expanded degrees of SGOT, SGPT, serum bilirubin and serum antacid phosphatase, upon prescription with the ethanolic 
roots extricate and inversion in their levels showing the hepatoprotective action ${ }^{[101,102]}$.

11. Anti-diarrhoeal: The ethanolic and aqueous concentrates have been appeared to have inhibitory action against gastrointestinal tract motility after intake of charcoal meal PGE2 incited enter pooling, taking loperamide as a kind of perspective medication ${ }^{[103]}$.

12. Immunomodulant Activity: $A$. racemosus polysaccharide fraction is used for the immune modulant activity [104]. It improves resistance through Tcells and brought about a huge expansion in immunizer titers demonstrating obvious humoral reaction. Steroidal sapogenins and steroidal saponins (shatavaroside an and shatavaroside B) are significant auxiliary metabolites present in Shatavri that may be described to show immunomodulatory impacts ${ }^{[105,106,107]}$.

13. Neural Disorders Activity: $A$. racemosus extract's potential examined against Kainic Acid (KA)-striatal neuronal damage and induced hippocampal ${ }^{[108]}$.

14. Anti-plasmodial Activity: The ethyl acetate extract of the roots of $A$. racemosus has been tested for antiplasmodia activity ${ }^{[109]}$.

15. Anti-inflammatory effects: $A$ racemosus root powder at the quantity of $200 \mathrm{mg} / \mathrm{kg}$ can reduce the tissue weight, inflammatory cytokine production, neutrophil mediated myeloperoxidase action, so it is consisting anti-inflammatory property [110].

\section{CONCLUSION}

Asparagus racemosus is generally known as Shatavari in Indian traditional system (Ayurveda). It is a well-known herb in Ayurveda. It is grown in the tropical areas of India, Sri Lanka and Himalayas. The plant is utilized generally as tonic for variety of diseases. It is also considered as a female reproductive tonic. The phytochemicals of the plant are widely distributed with many therapeutical properties. The main therapeutic use of the plant Shatavri is on the reproductive system of women and promotes learning and memory.

\section{Acknowledgement: None}

\section{Conflict of Interest: None}

\section{Source of Funding: None}

Ethical Approval: Not Applicable

\section{REFERENCES}

1. Raval PK, Nishteshwar K, Patel BR, Shukla VJ. Asparagus racemosus Willd.-"A Comparative Phytochemical Analysis of Fresh Dried Roots of Shatavari”. International Journal of Pharmaceutical \& Biological Archives. 2012.

2. Uniyal B. Utilization of medicinal plants by the rural women of Kullu, Himachal Pradesh. 2003.

3. Sharma PV. Dravyaguna vijnana, vol. ii. Chaukambha Bharati Academy, Varanasi. 2005.

4. Samhita C. Volume I-V. Chowkhamba Sanskrit Series Orientalia, Varanasi, India. 1970.

5. Sharma K, Bhatnagar M. Asparagus racemosus (Shatavari): a versatile female tonic. health. 2010.

6. Gurudeva MR. Botanical and vernacular names of south Indian plants. Divyachandra Prakashana; 2001.

7. Oketch-Rabaha HA. Phytochemical Constituents of the Genus Asparagus and their biological activities.1998.

8. Singh L, Kumar A, Choudhary A, Singh G. Asparagus racemosus: The plant with immense medicinal potential. Journal of Pharmacognosy and Phytochemistry. 2018;7(3):2199-203.

9. Bopana N, Saxena S. Asparagus Racemosus- Ethnopharmacological evaluation and conservation needs. Journal of ethnopharmacology. 2007 Mar

10. Gupta AK. Anonymous: Quality Standards of Indian Medicinal Plants. New Delhi. 2003. 
11. Goyal RK, Singh J, Lal H. Asparagus racemosus-an update. Indian journal of medical sciences. 2003.

12. Choudhary D, Sharma D. A phytopharmacological review on Asparagus racemosus. Int J Sci Res. 2014.

13. Kumar S, Mehla RK, Dang AK. Use of shatavari (Asparagus racemosus) as a galactopoietic and therapeutic herb-a review. Agricultural Reviews. 2008.

14. Sachan AK, Das DR, Dohare SL, Shuaib M. Asparagus racemosus (Shatavari): an overview. Int J Pharm Chem Sci. 2012.

15. Sachan AK, Das DR, Dohare SL, Shuaib M. Asparagus racemosus (Shatavari): an overview. Int J Pharm Chem Sci. 2012.

16. Sharma PC, Yelne MB and Dennis TJ. Database on medicinal plant. Central Council for Research in Ayurveda \& Siddha, Deptt. of ISM \& H, Min. of Health \& Family Welfare, Govt. of India.2000.

17. Joshi J, Dev S. Chemistry of Ayurvedic Crude Drugs. Part 8. Shatavari- 2: Structure Elucidation of Bioactive Shatavarin- I and Other Glycosides. ChemInform. 1988.

18. Gaitonde BB, Jetmalani MH. Antioxytocic action of saponin isolated from Asparagus racemosus Willd (Shatavari) on uterine muscle. Archives internationales de pharmacodynamie et de thérapie. 1969.

19. Subramanian SS, Nair AG. Occurrence of Diosgenin in Asparagus racemosus leaves. Cur Sci. 1969.

20. Hayes PY, Jahidin AH, Lehmann R, Penman K, Kitching W, De Voss JJ. Asparinins, asparosides, curillins, curillosides and shavatarins: structural clarification with the isolation of shatavarin $\mathrm{V}$, a new steroidal saponin from the root of Asparagus racemosus. Tetrahedron letters. 2006.

21. Sekine T, Fukasawa N, Kashiwagi Y, Ruangrungsi N, Murakoshi I. Structure of asparagamine $\mathrm{A}$, a novel polycyclic alkaloid from Asparagus racemosus. Chemical and pharmaceutical bulletin. 1994.

22. Sekine TN. TIFFNal Structure and relative stereochemistry of a new polycyclic alkaloid, asparagamine A, showing antioxytocin activity, isolated from Asparagus racemosus. Journal of Chemical Society, Perkin Trans. 1995.

23. Saxena VK, Chourasia S. A new isoflavone from the roots of Asparagus racemosus. Fitoterapia 2001.
24. Boger DL, Mitscher LA, Mullican MD, Drake SD, Kitos P. Antimicrobial and cytotoxic properties of 9,10dihydrophenanthrenes: structure-activity studies on juncusol. Journal Medicine Chemistry 1985.

25. Sekine TN, Fukasawa. A 9,10dihydrophenanthrene from Asparagus racemosus. Phytochemistry 1997.

26. Wiboonpun N, Phuwapraisirisan $P$, Tippyang S. Identification of antioxidant compound from Asparagus racemosus. Phytother. Res. 2004.

27. Kamat JP, Boloor KK, Devasagayam TP, Venkatachalam SR. Antioxidant properties of Asparagus racemosus against damage induced by gamma-radiation in rat liver mitochondria. J. Ethnopharmacol. 2000.

28. Sharma SC. Constituents of the fruits of Asparagus racemosus Willd. Pharmazie 1981.

29. Singh J, Tiwari HP. Chemical examination of roots of Asparagus racemosus. J. Indian Chem. Soc. 1991.

30. Choudhary BK, Kar A. Mineral contents of Asparagus racemosus. Indian Drugs. 1992.

31. Mohanta B, Chakraborty A, Sudarshan M, Dutta RK, Baruah M. Elemental profile in some common medicinal plants of India. Its correlation with traditional therapeutic usage. Journal of radioanalytical and nuclear chemistry. 2003.

32. Ahmad S, Ahmad S, Jain PC. Chemical examination of Shatavari (Asparagus racemosus). Bull Medico Ethnobotanical Res. 1991.

33. Subramanian SS, Nair AG. Chemical components of Asparagus racemosus. Current Science. 1968.

34. Subramanian SS, Nair AG. Occurrence of Diosgenin in Asparagus racemosus leaves. Cur Sci. 1969.

35. Tambvekar NR. Ayurvedic drugs in common eye conditions. J Natl Integ Med Assoc. 1985.

36. Handa SS, Suri OP, Gupta VN, Suri KA, Satti NK, Bhardwaj V, Bedi KL, Khajuria A, Kaul A, Parikh GG, Kulhar P, inventors. Process for the isolation of novel oligospirostanoside. United States patent US 6,670,459. 2003.

37. Mandal D, Banerjee S, Mondal NB, Chakravarty AK, Sahu NP. Steroidal saponins from the fruits of Asparagus racemosus. Phytochemistry. 2006. 
38. Kumeta Y, Maruyama T, Wakana D, Kamakura H, Goda Y. Chemical analysis reveals the botanical origin of shatavari products and confirms the absence of alkaloid asparagamine $\mathrm{A}$ in Asparagus racemosus. Journal of natural medicines. 2013 Jan 1;67(1):168-73.

39. Hayes PY, Jahidin AH, Lehmann R, Penman K, Kitching W, De Voss JJ. Steroidal saponins from the roots of Asparagus racemosus. Phytochemistry. 2008.

40. Sharma P, Chauhan PS, Dutt P, Amina M, Suri KA, Gupta BD, Suri OP, Dhar KL, Sharma D, Gupta V, Satti NK. A unique immuno-stimulant steroidal sapogenin acid from the roots of Asparagus racemosus. Steroids. 2011.

41. Ahmad S, Ahmad S, Jain PC. Chemical examination of Shatavari (Asparagus racemosus). Bull Medico Ethnobotanical Res. 1991.

42. Khare CP. Indian medicinal plants: an illustrated dictionary. Springer Science \& Business Media; 2008.

43. Paliwal MK, Siddiqui IR, Singh J, Tiwari HP. Chemical examination of roots of Asparagus racemosus. Journal of the Indian Chemical Society. 1991.

44. Bose S, Show S, Hazra M, Sarkar T. Comparative study of Antioxidant Activity of Herbal Drugs and their Formulations using Asparagus racemosus and Centella asiatica. Am J PharmTech Res. 2012.

45. Sabde S, Bodiwala HS, Karmase A, Deshpande PJ, Kaur A, Ahmed N, Chauthe SK, Brahmbhatt KG, Phadke RU, Mitra D, Bhutani KK. Anti-HIV activity of Indian medicinal plants. Journal of natural medicines. 2011.

46. Sharma U, Saini R, Kumar N, Singh B. Steroidal saponins from Asparagus racemosus. Chemical and Pharmaceutical Bulletin. 2009.

47. Sharma U, Kumar N, Singh B, Munshi RK, Bhalerao S. Immunomodulatory active steroidal saponins from Asparagus racemosus. Medicinal Chemistry Research. 2013.

48. Sekine T, Ikegami F, Fukasawa N, Kashiwagi Y, Aizawa T, Fujii Y, Ruangrungsi N, Murakoshi I. Structure and relative stereochemistry of a new polycyclic alkaloid, asparagamine A, showing antioxytocin activity, isolated from Asparagus racemosus. Journal of the Chemical Society, Perkin Transactions 1. 1995.

49. Singla R, Jaitak V. Shatavari (Asparagus Racemosus Wild): A Review On Its Cultivation, Morphology, Phytochemistry And Pharmacological Importance. International Journal of Pharmacy \& Life Sciences. 2014.

50. Sekine T, Fukasawa N, Murakoshi I, Ruangrungsi N. A 9, 10dihydrophenanthrene from Asparagus racemosus. Phytochemistry. 1997.

51. Wiboonpun N, Phuwapraisirisan $P$, Tip- pyang S. Identification of antioxidant compound from Asparagus racemosus. Phytotherapy Research: An International Journal Devoted to Pharmacological and Toxicological Evaluation of Natural Product Derivatives. 2004.

52. Saxena VK, Chourasia S. A new isoflavone from the roots of Asparagus racemosus. Fitoterapia. 2001.

53. Ahmad S, Ahmad S, Jain PC. Chemical examination of Shatavari (Asparagus racemosus). Bull Medico Ethnobotanical Res. 1991.

54. Saxena VK, Chourasia S. 5-Hydroxy 3, 6, 4'-Trimethoxy Flavone 7-O-beta-DGlucopyranosyl $\quad[1 \rightarrow \quad 4]-O-a l p h a-D-$ Xylopyranoside from Leaves of Asparagus racemosus. JOURNAL-INSTITUTION OF CHEMISTS INDIA. 2000.

55. Bopana N, Saxena S. Asparagus racemosus-Ethnopharmacological

evaluation and conservation needs. Journal of ethnopharmacology. 2007.

56. Singla R, Jaitak V. Shatavari (Asparagus Racemosus Wild): A Review On Its Cultivation, Morphology, Phytochemistry And Pharmacological Importance. International Journal of Pharmacy \& Life Sciences. 2014.

57. Symun N, Bushra F, Tuli D, Rashid UF, Tasnim TN, Sharmin A, Mou SM, Mohammed R. Ayurvedic influences in folk medicine: A case study of a folk medicinal practitioner of Jhalokathi in Barisal district, Bangladesh. American-Eurasian Journal of Sustainable Agriculture. 2013.

58. Alok S, Jain SK, Verma A, Kumar M, Mahor A, Sabharwal M. Plant profile, phytochemistry and pharmacology of Asparagus racemosus (Shatavari): A review. Asian Pacific journal of tropical disease. 2013. 
59. Kala CP. Aboriginal uses and management of ethnobotanical species in deciduous forests of Chhattisgarh state in India. Journal of Ethnobiology and Ethnomedicine. 2009.

60. Goyal RK, Singh J, Lal H. Asparagus racemosus-an update. Indian journal of medical sciences. 2003.

61. Warrier PK, Nambiar VP, Ganapathy PM. Some important medicinal plants of the Western Ghats, India. A Profile, IDRC, MAPPA, New Delhi, 2001.

62. Sairam K, Priyambada S, Aryya NC, Goel RK. Gastroduodenal ulcer protective activity of Asparagus racemosus: an experimental, biochemical and histological study. Journal of Ethnopharmacology. 2003.

63. Muddgal D. Dravyagun Vigyan. Ayurvedic Sanskrit Hindi Pushtak Bhandar. 2019.

64. WKBDS F, Perera KC. Gastro-Intestinal Effect of Shatavari Ghrita-A Literary Review. European Journal of Biomedical. 2019.

65. Sharma RK, Dash B. Caraka samhita [text with English translation and critical exposition based on Cakrapani datta's Ayurveda dipika]. India: Chowkhamba Varanasi. 2003.

66. Garde GK. Marathia translation of vagbhat'sastangahridya. Uttarstana: Aryabhushana Mudranalaya. 1970.

67. Srikantha MK. Appendix and indices. Varanasi: Krishnadas Academy. 1997.

68. Pizzorno JE, Murray MT, Joiner-Bey H. The Clinician's Handbook of Natural Medicine E-Book. Elsevier Health Sciences; 2016.

69. Frawley D. Ayurvedic healing: a comprehensive guide. Lotus Press; 2000.

70. Kalia V, Jadav AN, Bhuttani KK. In vivo effect of Asparagus racemosus on serum gonadotrophin levels in immature female wistar rats. In2nd world congress of Biotech. Dev. of Herbal Med. NBRI, Lukhnow 2003.

71. Naik BJ. Management of pre-eclampsia by ayurvedic drugs. J Nat Integrat Med Assoc. 1988.

72. Dwivedi M, Tewari PV. Dhatriyadi Yoga in obstetrics: Efficacy and cost. Sachitra Ayurved. 1991.

73. Vihan VS, Panwar HS. A note on galactogogue activity of Asparagus racemosus in lactating goats. Indian $\mathrm{J}$. Animal Health. 1988.
74. Hemadri K, Rao SS. Leucorrhoea and menorrhagia: Tribal medicine. Ancient Science of Life. 1983.

75. World Health Organization. Quality control methods for medicinal plant materials. World Health Organization; 1998.

76. Somani R, Singhai AK, Shivgunde P, Jain D. Asparagus racemosus Willd (Liliaceae) ameliorates early diabetic nephropathy in STZ induced diabetic rats.

77. Jagannath N, Chikkannasetty SS, Govindadas D, Devasankaraiah G. Study of antiurolithiatic activity of Asparagus racemosus on albino rats. Indian journal of pharmacology. 2012.

78. Yue J, Peng RX, Yang J, Kong R, Liu J. CYP2E1 mediated isoniazid-induced hepatotoxicity in rats. Acta Pharmacologica Sinica. 2004.

79. Garg DS, Agarwal JP, Garg DD. Shatawar. Dhanvantri. 1971.

80. Dev S. Ancient-modern concordance in Ayurvedic plants: some examples. Environmental Health Perspectives. 1999.

81. Kumar MV, Saima S, Vineet A, Nitin C. Effects of Asparagus racemosus, (shatavari) on mounting behaviour of male rats. International Journal of Pharmacy and Life Sciences (IJPLS). 2010.

82. Rao AR. Inhibitory action of Asparagus racemosus on DMBA-induced mammary carcinogenesis in rats. International journal of cancer. 1981.

83. Bhutani KK, Paul AT, Fayad W, Linder S. Apoptosis inducing activity of steroidal constituents from Solanum xanthocarpum and Asparagus racemosus. Phytomedicine. 2010.

84. Mitra SK, Prakash NS, Sundaram R. Shatavarins (containing Shatavarin IV) with anticancer activity from the roots of Asparagus racemosus. Indian journal of pharmacology. 2012

85. Kumar MS, Udupa AL, Sammodavardhana K, Rathnakar UP, Shvetha U, Kodancha GP. Acute toxicity and diuretic studies of the roots of Asparagus racemosus Willd in rats. West Indies medical journal. 2010.

86. Joshi RK. Asparagus racemosus (Shatawari), phytoconstituents and medicinal importance, future source of economy by cultivation in Uttrakhand: A review. Inter. J. Herb. Med. 2016.

87. Bhatnagar M, Sisodia SS. Antisecretory and antiulcer activity of Asparagus racemosus 
Willd. against indomethacin plus pyloric ligation-induced gastric ulcer in rats. Journal of herbal pharmacotherapy. 2006.

88. Forinash $\mathrm{AB}$, Yancey AM, Barnes $\mathrm{KN}$, Myles TD. The use of galactogogues in the breastfeeding mother, Ann Pharmacother. 2012.

89. Ramanathan M, Balaji B, Justin A, Gopinath N, Vasanthi M, Ramesh RV. Behavioural and neurochemical evaluation of Perment an herbal formulation in chronic unpredictable mild stress induced depressive model.2011.

90. Mangal A, Panda D, Sharma MC. Peptic ulcer healing properties of Shatavari (Asparagus racemosus Willd.). 2006.

91. Choudhary D, Sharma D. A phytopharmacological review on Asparagus racemosus. Int J Sci Res. 2014.

92. Mandal SC, Nandy A, Pal M, Saha BP. Evaluation of antibacterial activity of Asparagus racemosus Willd. root. Phytotherapy Research: An International Journal Devoted to Pharmacological and Toxicological Evaluation of Natural Product Derivatives. 2000.

93. Patel LS, Patel RS. Antimicrobial activity of Asparagus racemosus wild from leaf extracts-a medicinal plant. International Journal of Scientific and Research Publications. 2013.

94. Uma B, Prabhakar K, Rajendran S. Anticandidal activity of Asparagus racemosus. Indian journal of pharmaceutical sciences. 2009.

95. Onlom C, Khanthawong S, Waranuch N, Ingkaninan K. In vitro anti-Malassezia activity and potential use in anti-dandruff formulation of Asparagus racemosus. International journal of cosmetic science. 2014.

96. Bhatnagar M, Sisodia SS, Bhatnagar R. Antiulcer and antioxidant activity of Asparagus racemosus Willd and Withania somnifera Dunal in rats. Annals of the New York Academy of Sciences. 2005.

97. Wiboonpun N, Phuwapraisirisan P, Tippyang S. Identification of antioxidant compound from Asparagus racemosus. Phytotherapy Research: An International Journal Devoted to Pharmacological and Toxicological Evaluation of Natural Product Derivatives. 2004.

98. Kamat JP, Boloor KK, Devasagayam TP, Venkatachalam SR. Antioxidant properties of Asparagus racemosus against damage induced by $\gamma$-radiation in rat liver mitochondria. Journal of ethnopharmacology. 2000.

99. Karmakar UK, Biswas SK, Chowdhury A, Raihan SZ, Akbar MA, Muhit MA, Mowla R. Phytochemical investigation and evaluation of antibacterial and antioxidant potentials of Asparagus racemosus. International journal of pharmacology. 2012.

100. Kumar MS, Udupa AL, Sammodavardhana K, Rathnakar UP, Shvetha U, Kodancha GP. Acute toxicity and diuretic studies of the roots of Asparagus racemosus Willd in rats. West Indies medical journal. 2010

101. Muruganadan S, Garg H, Lal J, Chandra S, Kumar D. Studies on the immunostimulant and antihepatotoxic activities of Asparagus racemosus root extract. J Med Arom PI Sci. 2000.

102. Om FR, Kumar R, Mani T, Niyas MK, Kumar SB, Phaneendra P, Surendra B. Hepatoprotective activity of Asparagus racemosus root on liver damage caused by paracetamol in rats. Indian $\mathbf{J}$ Novel Drug Delivery. 2011.

103. Venkatesan N, Thiyagarajan V, Narayanan S, Arul A, Raja S, Kumar SV, Rajarajan T, Perianayagam JB. Antidiarrhoeal potential of Asparagus racemosus wild root extracts in laboratory animals. $\mathrm{J}$ Pharm Pharm Sci. 2005.

104. Kumar MV, Saima S, Vineet A, Nitin C. Effects of Asparagus racemosus,(shatavari) on mounting behaviour of male rats. International Journal of Pharmacy and Life Sciences (IJPLS). 2010.

105. Gautam M, Saha S, Bani S, Kaul A, Mishra S, Patil D, Satti NK, Suri KA, Gairola S, Suresh K, Jadhav S. Immunomodulatory activity of Asparagus racemosus on systemic Th1/Th2 immunity: implications for immunoadjuvant potential. Journal of ethnopharmacology. 2009.

106. Sharma P, Chauhan PS, Dutt P, Amina M, Suri KA, Gupta BD, Suri OP, Dhar KL, Sharma D, Gupta V, Satti NK. A unique immuno-stimulant steroidal sapogenin acid from the roots of Asparagus racemosus. Steroids. 2011 Mar 1;76(4):358-64.

107. Bharati J, Kumar S. Shatavari (Asparagus racemosus). 
108. Bhattacharya SK, Bhattacharya A, Chakrabarti A. Adaptogenic activity of Siotone, a polyherbal formulation of Ayurvedic rasayanas, Indian $\mathrm{J}$ Exp Biol. 2000.

109. Kaushik NK, Bagavan A, Rahuman AA, Mohanakrishnan D, Kamaraj C, Elango G, Zahir AA and Sahal D. Antiplasmodial potential of selected medicinal plants from Eastern Ghats of South India. Exp Parasito 2013.
110. Gyawali R and Kim KS: Bioactive volatile compounds of three medicinal plants from nepal. Kathmandu Uni J Sci Eng Technol 2011.

How to cite this article: Thakur S, Kaurav H, Chaudhary G. Shatavari (asparagus racemosus) - the best female reproductive tonic. International Journal of Research and Review. 2021; 8(5): 73-84. DOI: https://doi.org/ 10.52403/ijrr.20210511 